\title{
Technological determinants of the lifetime well-being in the 21th century
}

\author{
Sergey Zhironkin ${ }^{1}$, Eyvaz Gasanov ${ }^{2}$, Olga Zhironkina ${ }^{3}$, Ekaterina A. Taran ${ }^{1, a}$ \\ ${ }^{1}$ Tomsk Polytechnic University, 634050 Lenin Avenue, 30, Tomsk, Russia \\ ${ }^{2}$ Khabarovsk State Academy of Economics and Law, 680042 Tikhookeanskaya str., 134, Khabarovsk, Russia \\ ${ }^{3}$ Kemerovo branch of Plekhanov Russian University of Economics, 650992 Kuznezky Avenue, 39, Kemerovo, Russia
}

\begin{abstract}
The paper deals with technological determinants of the lifetime social well-being, as conditions of maintaining the level and style of consumption, social status throughout the whole life. Despite the high importance of the problem of the social well-being and the relevance of its solution for the development of modern society, the issues of its correlation with the technological level of production and the development of information technologies are still poorly researched. As the problem of the life-time wellbeing take on special significance, it is important to analyze its conditions, related not only to social benefits, but also to the scientific and technological progress. For the future innovation and the digital stage of social well-being is its network well-being. It is based on the usage of the Internet for professional activity and personal self-fulfillment during the whole conscious life. Network well-being also reflects the convergence of information and network, industrial, financial, marketing, and social technologies. The formation of the life-time network well-being requires from the Government some measures of social adjustment, fiscal policy and the regulation of employment to encourage Internet Education and Internet employment, enhancing the prestige of working in high-tech industries.
\end{abstract}

\section{Introduction}

The social well-being, its objective content, subjective perception, factors and evaluation criteria are the subject of debate among contemporary economists. We identified two main approaches to the analysis of the social well-being: an objective (Bartel, Lichtenberg (1991) [1], Rahn, Brehm (1997) [2], Gurley, Harter (2008) [3]), and object-subject approach (Diener (2005) [4], Berkman, Glass, Brissette, Seeman (2008) [5], Melchior, Niedhammer, Berkman, Goldberg M. (2003) [6], Kahneman, Riis (2005) [7], Barysheva (2015) [8]). An objective approach considers the well-being from "outside" - by the society, its current standards to ensure a minimum living standard. The well-being here is associated with the volume of material, non-material and social benefits, which an individual or household can "take" from the society according to her/his education, profession, age, and so on, and which the society can give her/him. An object-subject approach considers both an external (social) and internal (personal) basis of the social well-being and is based on integration of four concepts: internal agreement of the individual with herself/himself; understanding of personal benefit, access to its source and the intention to get it; realization of personal potential in work and creativity; availability of opportunities to get exactly those goods that are necessary for personal development. Gallup, Hill (1960)

\footnotetext{
${ }^{\mathrm{a}}$ Corresponding author: ektaran@tpu.ru
}

[9], Max-Neef (1995) [10], Deaton (2008) [11], Gasanov, Zhironkin (2015) [12] thoroughly analyzed the problem of the lifetime social well-being. In general, it is considered as a set of external conditions, economic opportunities, personal values and professional skills, allowing receiving certain benefits during the whole life. Fields, Yoo (2000) [13] point to "lifetime employment" in Japanese corporations, and Christman (2014) [14], Coons, Weber (2013) [15] point to the social paternalism in the socialist countries as an attempt to approve the lifetime well-being.

\section{Methods}

The main factors of social well-being continuity are the high performance in professional career, allowing "saving for a poor less old age", as well as a high level of social benefits (pensions, disability benefits, child care). At the same time, the volatility of the economic dynamics and the cyclical nature of the market economy do not allow guaranteeing sustainable well-being for 5060 years or more - the period from the start of working activity until the end of human life in the developed countries. Several types of fluctuations can be observed during this period - medium industrial cycles of Juglar and construction cycles of Kuznets, long Kondratieff waves. But in the Russian transitive economy and the 
economies of former socialist countries, social and economic problems of the transformational nature are added to the cycles typical for market economy. They include lack of innovation in production and a low level of wages, poor government funding of social payments, large social stratification, lack of investment, high interest rates on loans. As a result, lifetime neo-industrial well-being indicators in Russian economy are much lower than in countries - industrial leaders. If in the USA in 2013 the income of specialists with higher education 2,1 times as much exceeded the income of workers without one, in Russia this excess amounts to 1,4 times (excluding civil servants). In the US more than $90 \%$, in Germany more than $70 \%$, in Western Europe more than $90 \%$ of graduates pursue their specialty, in Russia - less than $60 \%$ (the US Department of Labor, 2011) [16]. The average salary in industry in Russia in 2013 (\$910) is 4,5 times less than in Germany and 5 times less than in the US (US Census Bureau, 2010 [17]). Capitalization of households' income in Russia does not exceed an average of 18, 6 thousand USD, which is almost 6 times lower than in Germany and 18 times less than in the US. The ratio of material and non-material goods consumption in Russia is in average of 1 to 7 ; in Germany and the US it is 1 to 3 and 4 (OECD, 2014) [18]. Interest rates on consumer loans in Russia exceed 2-2, 5 times as much the level of Eastern European countries, 3-3,5 times as much - of Western Europe, 4 times as much - of the USA. The minimum pension paid by the government in Russia is 8 times less than that in the United States, and 6 times less than that in EU countries. Mutual pension funds are just forming in Russia (Joe, 2011) [19].

Currently, in the Russian economy the main indicators of social well-being went down as a result of two-time devaluation of the rouble against the US dollar and the euro in 2014-2015. In general, indicators of social well-being in the Russian economy reflect the negative impact of deterioration of investment conditions in industrial production, the development of innovation, forcing the process of structural de-socialization. It is a destruction of the social groups that can provide innovative development and income growth in the longterm period. Formation of the lifetime well-being in the Russian economy is constrained by such problems as difficulties experienced by university and college graduates when setting up in employment owing to the educational profile, low salaries in industry, a large share of underground economy, and a low level of pensions. In fact, we can speak about the achievement of social wellbeing only in case of the Russians of working age, who receive a stable income. Upon reaching old age and retirement, provision of material goods in Russia is significantly reduced. The main cause of the discrete nature of social well-being in Russia is its suspended approaching the late-industrial stage of economic development, with its high labor productivity and wages, increased requirements to education and professional knowledge of workers and their income.

\section{Discussions}

To analyze the growth conditions of social well-being in Russian economy, we have identified the technological determinants and platform, and bound them to the factors of social well-being:

- Technological determinants of social well-being are means of production of goods, determining their availability to the general public, the borders of highlypaid employment and the limit level of labor productivity;

- A technological platform - a set of technologies that can change the dominant means of production of goods, cause a qualitative leap in labor productivity and create conditions for the transition to the next stage of social well-being. The concept of technological platforms also includes enterprises that can implement "technologies of the future" in routine activities, make new demands to employees, provide them with stable employment, increase their incomes, bring tax revenues to the state budget at a higher level;

- Factors of transition to a new level of social wellbeing - the powers originating in different processes in economy and society and changing the structure of national economy.

The sequence of historical stages of social well-being we have presented in the following way. The first is a traditional stage of social well-being (until the early 19th century). Its technological determinants were different means of natural resources processing (agriculture, mining, and construction). Traditional pre-industrial sectors were an emerging engineering, mass production of clothing and footwear, furniture and building materials, rolled metal products. As technologies of the traditional stage improved the transition to the next stage, the beginning of industrial development started. Its guidelines having appeared in the form of innovative ideas and inventions in the 19th century were heat-power engineering, flow and line production systems, construction of megacities. These ideas gradually formed the early-industrial technological platform of the late 19 th - early 20th centuries connected with the processing of minerals, urbanization, energy production, transcontinental transportation and emerging financial markets. The origin of industrial technological platform was contributed by the factors that determine the future of social well-being (by the early 20th century) migration of rural inhabitants to cities, mastering of industrial jobs by them, the growth of total literacy. It was required from the state to establish the system of modern social guarantees - pensions and benefits, covering the physical needs of an individual.

Today, the traditional technological determinants are characteristic features of such countries as Bangladesh, the countries of Central Africa, Tajikistan, Uzbekistan, and some South American countries. In these countries the share of the poor is at the level of $40-45 \%$ (according to the World Bank), incomes are below $\$ 1,25$ per capita per day, the lifespan is 55-60 years. In Russia, this technological basis determines the social well-being in such regions as Ivanovo, Astrakhan region, Krasnodar region, the Republic of Buryatia and Tuva. The quintessence of the social well-being growth for these areas is decreasing the proportion of the poor by less 
than half of the population, as well as guaranteeing the simple reproduction of the labor force (which is important today for a number of Asian and African countries, as well as for some regions in Russia).

On the second, early-industrial stage (the first half of the 20th century) the well-being growth was stipulated by the technological determinants of the industrial sector - the production of available electricity, intra- and transcontinental transportation, deep processing of mineral resources, line production of consumer goods. "Centers of gravity" of these technologies have become such industries as electricity, modern machinery, plastics, aviation, and electronics. Having been formed in the first half of the 20th century the technological platform of transition to the late-industrial stage was connected with full automation of labor-intensive, hazardous industries, development of the service sector of economy and the concentration of high-tech industries in the manufacturing clusters in the United States, Britain, France, Germany, Italy. The guidelines of the future technological development in the middle of the 20th century became the production of non-material goods, calculating, invention, travelling, and higher education. Accordingly, factors of social well-being growth which existed in the first half of the 20th century and had to define it up to the end of the 20th century became small business, vocational training, international migration of scientists and specialists, a career of a manager. In order to realize these factors the government should have taken control over labor relations, cooperated with the trade unions, increased social benefits. At the macroeconomic level the conditions of the transition from early to late-industrial stage of social well-being were the following: the ratio of investment in the manufacturing sector to the mining one $-1,3$; the share of investment in R\&D in GDP is more than 5\%; the share of private investment in shares in GDP is more than $10 \%$.

Today, the social well-being of the early-industrial stage can be found in the countries of Eastern Europe (Poland, Slovakia, Croatia, Romania), Russia, India, as well as Brazil, Argentina and Australia. In Russian earlyindustrial technological determinants form social wellbeing in Kemerovo, Tyumen, Irkutsk, Sverdlovsk Regions, Krasnoyarsk Territory, the Republic of Tatarstan and Bashkortostan, which are among the industrialized regions. The indicators of social wellbeing in the early-industrial stage reflect decreasing of the share of poor population and the growth of material goods consumption. Thus, the proportion of the poor does not exceed $25 \%$, more than half of income is spent for living, and consumption of material goods is 4-7 times more than non-material ones.

The third - the late-industrial stage of the social wellbeing growth (the second half of the 20th century) is associated with approaching to the exhaustion of technological determinants of industrial production, with an increased role of intellectual capital accumulation and the development of the service sector. Technological determinants of social well-being of the second half of the 20th century are the processes of replacement of human beings by machines - robotics, micro-processing, operations with arrays of data, global logistics, vertical integration of research and production. Today it is important for such countries as Finland, South Korea, Singapore, and Taiwan. China is gradually approaching these countries according to these criteria. The technological transition platform to the new digital and innovation stage of social well-being is being formed in these countries. It consists of general IT-development and digitalization of production processes, integration of scientific research, conceptual modeling, pilot and mass production. Technological benchmarks of social wellbeing in the nearest future are "breakthrough" convergence technologies - grid computing, laser science, genetic engineering, network programming, nano-materials production. Factors, which should determine the outcome of social well-being to a new level in the 21 st century, include private venture capital investments, massive scientific activities, small innovative entrepreneurship, and career in research institutions.

The late-industrial social well-being is characterized by a low proportion of the poor (not more than 15\%), high income of employees having higher education (especially of those employed in the scientific field), the growth of non-material goods consumption. In Russia, the prospects of achieving the late-industrial stage of social well-being we associate with the formation of innovation clusters in Moscow and Leningrad region, Tomsk, Novosibirsk.

In order to transit to the technological base of social well-being it is necessary to achieve such social guidelines as a guarantee of employment in processing and hi-tech sectors, availability of modern higher education. At the macroeconomic level it requires the achievement of the following proportions:

- The ratio of consumption of material and nonmaterial benefits $-2 / 1$;

- The ratio of the income of employees with higher education and without it - 3 ;

- The number of staff in research and development per 10000 employees - 150 .

With the gradual development of the technological platform of the future, achievement of macroeconomic and social targets, a transition to a new stage of social well-being growth, which will determine its level in the 21 st century, is possible.

This fourth - oncoming innovation and the digital stage of social well-being will be based on such determinants as mass involvement of people in the information business and innovative entrepreneurship based on globally diffused network information, nanoand bio-technologies. These determinants of social wellbeing are implemented, primarily in information and scientific (R\&D) sectors of economy where business is "connected" with data processing, generation, commercialization and diffusion (spreading) of innovations.

Industrial convergence should become the technological platform of innovation and the digital stage of the social well-being growth. It consists in interpenetration and combination of different technological innovations united by the common digital 
form of design, replicating and diffusion. Industry convergence also means the development of multiplatform innovations in existing clusters, worked out on different technological platforms, but being able to give a common product. As the examples of convergent products it is possible to name non-waste production technology of ecologically clean fuel, cloud computing and laser computer science, production of bio-plastics materials, and small space program.

We define such factors, which will determine the social well-being in the $21 \mathrm{st}$ century, as the use of network information technology, private investments in education, work in network clusters, patenting of inventions and obtaining intellectual rent.

Today, Great Britain, the USA, Germany, Japan are coming to this digital-information stage. Well-being standards here are defined by the prevalence of expenditure for non-material benefits over the material ones, due to the rapid growth of scientific sector. In these countries the share of households' expenditures for health care, better education, a variety of entertainments is up to $60 \%$ of income.

Creating conditions for the social well-being growth in Russian economy means the transition from the earlyindustrial stage to the late-industrial one, with simultaneous creation of innovation-digital stage. For Russian economy, such transition is possible only with recovering of manufacturing industry based on new technology, and developing of high-tech industries on a wide natural resource base. The technological transition platform to the late-industrial stage of social well-being in Russia is the production of non-material goods in the fields of information, scientific and educational services, travelling sector.

Targets indicators of social well-being, specific for innovation-digital stage, include the excess of investments in manufacturing sector over extractive one at least in $30 \%, \mathrm{R} \& \mathrm{D}$ investments should be at the level of not less than $5 \%$, while private investments in shares $10 \%$ of GDP. These target well-being guidelines should be included in the government program of structural reforms. In order to achieve them, the state needs to provide availability of modern higher education, to ensure employment in the manufacturing and high-tech sectors of economy, to create the most favorable conditions for private ventures and small business innovation, greatly enhance the prestige of employment in scientific sector.

For Russia, the acceleration of the transition to the digital-innovation stage of neo-industrial social wellbeing requires the creation of platforms with converged technologies together with private investment in higher education of the global level, employment in a networked cluster, use of licensed network information technologies. These will allow achieving the target indicators of social well-being which will characterize it as a network: a two-fold excess consumption of nonmaterial goods over material ones, the proportion of staff in the field of scientific research to the total amount of the employed - 1 to 650 .

At the innovation-digital stage the network social well-being, based on the convergence of computing, social and industrial technologies, is being formed. Network well-being means the complex of conditions that allows people, familiar with modern information technologies and highly qualified in their professional activity, earning money, benefits and realize professional self-fulfilment (Kang, Yoon, Kim J., Kim H. (2008) [20]). These conditions are linked to employment via the Internet - professional medical, legal, financial consulting, international scientific cooperation, global marketing, school and university tutoring, business training and so on.

Despite the fact that today, the basic form of the network well-being is the creating of computer programs in the remote work for large corporations, in future network clusters will inevitably appear. They will integrate a great number of experts, scientists, entire research organizations, universities, data centers of large enterprises via the Internet. Their activities will be intercluster and cross-platform in nature, due to digitalization of scientific research process, and unite the creation of innovation in separate clusters and individual technological platforms.

It is the network social well-being that can be considered as truly life-time, allowing realizing professional skills through the whole life, thanks to the provision of services via the Internet, as well as obtaining life-time intellectual rent. Today, senior citizens have got an access to an unlimited source of information via the Internet (in general in Russia - more than half of the households). First of all, this information facilitates the obtaining of the most important social services - the timetable of transport, information about free medical services, advertising of discounts and forums, hobby. Also, for senior citizens communication via the Internet social networks has become very important.

At the same time, the Internet provides opportunities for senior citizens to support actively their well-being in the process of continuous learning and working as consultants according to their profession, participation in marketing activities (surveys, data analysis, and expert assessment), study the technology of website design and creation of Internet sites.

\section{Conclusion}

As the achievement of lifetime well-being should be based on the technological determinants of innovation a digital stage of society development - it must penetrate into all its age and gender structure. In this regard, a set of measures in innovation, social, fiscal and employment regulation is required from the government:

- Government order for the mass training of Russian specialists in leading foreign universities in the fields of advanced technologies, with the obligatory further employment in the companies - residents of innovation clusters and technology parks;

- Development of state employment guarantees for highly skilled workers and university graduates according to their educational profiles corresponding to critical technologies; 
- The exemption of employees' payroll in innovative firms, R \& D organizations from all taxes, and those engaged in the innovation sector from the individual income tax;

- Restoration of the scientific work prestige, employment in the scientific sector, social mobility based on high profitability of innovation, invention and engineering creativity;

- Legal protection of intellectual property rights, development of the market of licensed and patent technologies and know-how, the guarantee of obtaining the intellectual rent by the owners of intellectual capital;

- The creation of supporting programs in involvement of senior citizens in the network well-being, their education, training and employment via the Internet.

Thus, the lifetime social well-being is quite attainable for any modern economy, including the Russian one. Its key driver should become not the increasing of social payments by the state, but penetration of new network technologies in various aspects of public and private life.

\section{Acknowledgment}

The study was conducted at Tomsk Polytechnic University with financial support of the Ministry of Education and Science of the Russian Federation in the framework of the scientific research "Evaluation and enhancement of social, economic and emotional wellbeing of older adults" contract № 14.Z50.31.0029. The authors would like to thank Victor Kanov for their discussion during the study. We thank the anonymous referees for their constructive and useful comments on the paper.

\section{References}

1. A.P. Bartel, F. Lichtenberg, NBER WP, 2732, (1991)

2. W. Rahn, J. Brehm, AJPS, 41, 999-1023 (1997)

3. J. Harter, V. Gurley, APS, 12, 23-26 (2008)

4. E. Diener, SINET, 84, 4-6 (2005)

5. L. Berkman, T. Glass, I. Brissette, T. Seeman, Soc Sci Med, 6, 843-857 (2000)

6. M. Melchior, I. Niedhammer, L. Berkman, M. Goldberg, JECH, 57(4), 285-293 (2003)

7. D. Kahneman, J. Riis, The science of well-being (NY OUP, 2005)

8. G. Barysheva, I. Kashchuk, Procedia Soc. Behav. Sci., 166, 62-68 (2015)

9. G.H. Gallup, E. Hill, The secrets of long life. (NY, Geis Associates; Random House, 1960)

10. M. Max-Neef, Ecological Economics, 15(2), 115118 (1995)

11. A. Deaton, JEP. 22(2), 53-72 (2008)

12. S. Zhironkin, M. Gasanov, Procedia Soc. Behav. Sci., 166, 97-102 (2015)

13. G.S. Fields, G. Yoo, Rev. Income Wealth, 46(2), 139-159 (2000)

14. J. Christman, ETMP, 17(3), 369-382 (2014)

15. C. Coons, M. Weber, Paternalism: Theory and Practice (Cambridge, CUP, 2013)
16. U.S. Department of Labor. Bureau of Labor Statistics. The employment situation. Available at: http://www.bls.gov/news.release/empsit.toc.htm [Accessed: 27.08.2015]

17. U.S. Census Bureau. Income, Poverty, and Health Insurance Coverage in the United States. Available at:

https://www.whitehouse.gov/blog/2015/09/16/inco me-poverty-and-health-insurance-united-states-2014 [Accessed: 27.08.2015]

18. OECD. Economic Outlook. Available at: http://www.oecd-ilibrary.org/economics/oecdeconomic-outlook-volume-2014-issue1_eco_outlook-v2014-1-en [Accessed: 20.08.2014]

19. G. Joe, Oxford Review of Economic Policy, 27, 620-633 (2011)

20. M.H. Kang, H.J. Yoon, J.S. Kim, H.S. Kim, Journal of Educational Technology, 24(3), 23-51 (2008) 